mentów, bo każdy Sakrament jest spotkaniem z całym Chrystusem, a więc i z Jego mistycznym Ciałem. (por. Ks. W. S chen k, Liturgia Sakramentów św., Cz. I-II, Lublin 1962-64).

Sakramentalia przypominają fakt, że przez Wcielenie Chrystusa zostal uświęcony cały świat (consecratio mundi), że człowiek przez używanie wszystkich dóbr zgodnie z Wolą Bożą chwali Stwórce wszechrzeczy.

Rok liturgiczny nie jest jedynie przedstawieniem i przypomnieniem faktów minionych czasów. Jest to raczej sam Chrystus, który trwa $w$ Kościele swoim i kroczy droga ogromnego miłosierdzia swego, która rozpoczą za swego życia (Mediator Dei, s. 90) W liturgii każdego święta jest obecny i działa Chrystus, w liturgii jest zawsze „dziś - hodie", przy czym snop światła oświetla po kolei poszczególne momenty bogatego życia Jezusa, wydobywając poszczególne klejnoty skarbca Jego Serca, którego echem i odbiciem sa cnoty Świętych Pańskich, a zwłaszcza Jego Matki Najświętszej.

Reforma liturgii i udział wiernych w niej osiągają wtedy swój cel, gdy przynoszą trwały owoc, a mianowicie upodobnienie do Chrystusa. Upodobnienie to (homo conformatus Christo) jest owocem dlugiej pracy nad sobą przez codzienne, coniedzielne włączenie się w misterium paschalne Pana, tzn. w Jego przejście przez śmierć i zmartwychwstanie do życia w chwale u Ojca. Wtedy uczestnicy w liturgii stawszy się zaczynem Chrystusowym i solą ziemi, zwiastować będą życie Boże na ziemi i przelewać je na innych:

Bytom

Ks. WACEAW SCHENK

\title{
WSPÓLNA MODLITWA WIERNYCH
}

\section{(,Wypominki”)}

WSTEP

Soborowa Konstytucja o Liturgii św. wydała następujące pouczenia i postanowienia odnośnie do wspólnej modlitwy wiernych (Art. 53):

„Po Ewangelii: homilii, należy przywrócić „modlitwę powszechną” czyli „modlitwę wiernych”, zwłaszcza w niedziele i święta nakazane, aby z udziałem wiernych odbywały się modlitwy za Kościół święty, za tych, którzy nami rządzą, za tych, którzy znajdują się w różnych potrzebach oraz za wszystkich ludzi i o zbawienie całego świata".

A oto, co mówi o tej modlitwie Instrukcja do należytego wprowadzenia w życie konstytucji o świętej Liturgii z dnia 26 września 1964 r. (n. 56):

„W miejscach, w których już istnieje zwyczaj odmawiania modlitwy powszechnej albo wiernych przed offertorium, po odmówieniu oremus niech się na razie odmawia nadal, według przepisów obowiązujących w poszczególnych krajach. Celebrans niech kieruje tą modlitwą albu z krzesła (sedes), albo od ołtarza, albo przy pulpicie, albo przy balaskach. 
Intencje względnie prośby może śpiewać diakon albo kantor, albo inny odpowiedni ministrant (idoneus minister), pozostawiając dla celebransa słowa wstępne i modlitwę na zakończenie, którą zwykle niech będzie modlitwa: Deus, refugium nostrum et virtus (por. Missale romanum orationes diversae n. 20), względnie inna bardziej odpowiadająca szczególnym potrzebom ${ }^{1}$.

W miejscach zaś, w których nie ma zwyczaju odmawiania modlitwy powszechnej albo wiernych, kompetentna władza terytorialna może zadecydować, aby ją odmawiano na sposób wyżej określony, według formıł na razie przez nią samą zatwierdzonych".

Niniejsza książeczka ma na celu wyjaśnić i wytłumaczyć owe modlitwy tak, aby właściwym władzom kościelnym dostarczyć danych do ich ułożenia oraz norm, które należy zachować przy zatwierdzaniu odnośnych tekstów modlitewnych.

Z Citta di Vaticano, 13 stycznia $1965 \mathrm{r}$.

z polecenia

Przewodniczącego Komisji

A. Bugnini C. M.

Sekretarz

ROZDZIAE I

\section{WSKAZOWKI PRAKTYCZNE \\ CO TO SA MODLITWY POWSZECHNE (WYPOMINKI) \\ ICH ZNACZENIE W DUSZPASTERSTWIE}

1. Modlitwa powszechna (wypominki), czyli wspólna modlitwa wiernych, są to prośby zanoszone do Boga przez zgromadzenie wiernych pod przewodnictwem celebransa (lub odpowiedniego ministranta) w różnych intencjach Kościoła i świata.

2. Oto trzy zasadnicze cechy tej modlitwy:

a. Jest ona prośba skierowaną do Boga: a więc nie chodzi tu tylko o uwielbienie Boga czy dziękczynienie albo też uczczenie świętych. Modlitwa, o której mowa, nie polega też na przypomnieniu róźnych prawd dotyczących obowiązku kultu albo istoty mszy świętej.

b. Jest ona powszechna: chce wyprosić u Boga wielorakie łaski dla Kościoła, dla świata i dla wszystkich potrzebujących pomocy Bożej. Niemniej należy modlić się również w intencjach wiernych uczestniczących w tej modlitwie.

c. Jest prawdziwą modlitwą wiernych, ponieważ zebrani mają odpowiadać na każde wezwanie kapłana, a nie poprzestawać na jednej tylko odpowiedzi po wszystkich intencjach wyliczonych przez celebransa.

3. Wspólna modlitwa wiernych ma być wprowadzona nie tylko podczas mszy świętych, lecz i poza nimi "w nabożeństwach i różnych czynnościach liturgicznych", jak to ujmuje Soborowa Konstytucja o Liturgii świętej (art. 118). Dzięki wypominkom Kościół Boży, zebrany na modli-

1 N. B. Melodie dla wspólnej modlitwy wiernych, które można dostosować do tekstów mających uzyskać aprobatę właściwej władzy kościelnej podane są w dodatku, który opuszczamy; wydane są też osobno pt.: "Cantus, qui in Missali romano desiderantur, iuxta Instructionem ad exsecutionem Constitutionis de sacra Liturgia recte ordinanda et iuxta ritum Concelebrationis" (Typis Poliglottis vaticanis 1965). 
twie, wyrażając swoją niezachwianą wiarę w świętych obcowanie a zarazem i w swoje własne powołanie, ukazuje się oczom ludzkim jako ten, który za nimi oręduje i prosi. Lud Boży wykonywuje swoje króleskie kapłaństwo przede wszystkim przez uczestnictwo sakramentalne, ale też i przez zanoszenie do Boga niniejszych błagań. Wypominki mają być odmawiane przez wiernych nie zaś przez katechumenów.

4. Wspólna modlitwa wiernych zajmuje wyorane miejsce we mszy świętej: jest ona jakby pomostem łączącym dwie jej części. Z jednej strony stanowi zakończenie Liturgii Słowa uprzytomniającej nam cudowne sprawy Boże i nasze powołanie chrześcijańskie; z drugiej zaś, wprowadza do Liturgii Ofiary wymieniając także niektóre spośród tych intencji, czy to powszechnych czy też bardziej indywidualnych, za które składa się ofiarę.

5. Ponieważ zwyczaj odmawiania wspólnej modlitwy wiernych ma doniosłe znaczenie i stanowi normalną część mszy świętej, powinno się ją jak najczęściej odmawiać, a „zwłaszcza ma być przywrócona w niedziele i święta nakazane" (Konst. art. 53), ale również i w tygodniu we wszystkich mszach odprawianych z udziałem wiernych.

\section{§ II. STRUKTURA TEJ MODLITWY ORAZ SPOSÓB JEJ ODMAWIANIA}

6. Wypominki składają się z następujących części: podawanie intencji, odpowiedzi wiernych, formuły zakończenia. Między poszczególnymi częściami można dodać parę słów wprowadzających.

7. Celebrans powinien bowiem krótko zachęcić wiernych do tej modlitwy, ponieważ ma to wielkie znaczenie tak liturgiczne jak i duszpasterskie. Celebrans zwraca się więc do wiernych, nie do Boga. W swym przemówieniu może nawiązać do okresu liturgicznego, do święta czy uroczystości ku czci świętego na ten dzień przypadających, wyprowadzając z nich niejako treść wspólnej modlitwy. To przemówienie można opuścić dla słusznej przyczyny, zwłaszcza jeśli bezpośrednio przedtem była homilia.

8. Stosownie do dawnego zwyczaju kościoła rzymskiego celebrans może sam podawać wiernym intencje modlitwy, Instrukcja jednak (n. 56) powierza ten obowiązek w sposób szczególny diakonowi.

We mszach świętych bez diakona intencje podaje komentator, albo sam celebrans, lub jeden z koncelebrujących albo też ktoś, kto godnie to uczyni.

Jeżeli modlitwa wiernych jest śpiewana (czego należałoby sobie życzyć), wtedy zapowiadający intencje powinien umieć dobrze śpiewać.

Jeżeli celebrans osobiście nie zapowiada intencji, to wtedy odpowiada na nie wraz z wiernymi; nie może też zacząć ofiarowania przed zakończeniem owej wspólnej modlitwy wiernych (por. co powiedziane w Instrukcji n. 66 i 72 o Bierzmowaniu i sakramencie małżeństwa udzielanych w trakcie mszy św.).

9. Po wstępnym kapłańskim słowie zachęty (w schematach niżej podanych nazwiemy je sekcją ,A") podawane są intencje, w których należy się modlić. Dzielą się one zazwyczaj na cztery grupy (a wyjątkiem wypadków wymienionych w $\mathrm{nr} 10$ ), mianowicie:

Sekcja B) za potrzeby Kościoła powszechnego: np. za Papieża, za Sobór, za Hierarchię, za misje, o zjednoczenie chrześcijan, o powołania kapłańskie i zakonne itd.

Sekcja C) Sprawy narodowe i światowe np. o pokój, za rządzących państwami, o zachowanie od klęsk żywiołowych, o dobre zbiory, w intencji wyborów, w okresie kryzysów ekonomicznych itp. (por. poniżej sekcja C). 
Sekcja D) za wszystkich dotkniętych niedostatkiem lub walczących z trudnościami, np. za nieobecnych, prześladowanych, bezrobotnych, chorych i cierpiących, za konających, za więźniów wygnańców itp. (por. poniżej sekcja D).

Sekcja E) za wiernych zebranych w kościele i sprawy miejscowej gminy chrześcijańskiej, np. za mających otrzymać chrzest, bierzmowanie albo święcenia, za przygotowujących się do małżeństwa, za duchowieństwo parafialne, w intencji misji czy rekolekcji parafialnych, w intencji przystępujących do pierwszej komunii św. itd. (por. poniżej sekcja E).

Z każdej z powyższych grup należy wybrać przynajmniej po jednej intencji.

10. W wypadku okolicznościowego nabożeństwa np. z okazji ślubu, pogrzebu itp. należy szerzej uwzględnić intencje partykularne $z$ tym obchodem związane, nigdy jednak nie można opuścić całkowicie intencji ogólnych, o których była mowa powyżej.

11. Jeżeli chodzi o formę w jakiej te intencje są ujęte, jest ona trojaka (por. rzut oka historyczny str...):

a) forma pełna (módlmy się za... aby...). Wymienia się tu tych, za których się modlimy i to o co dla nich prosimy. W ten też sposób - ujęte są wezwania modlitewne w Wielki Piątek.

b) forma niepełna pierwsza (módlmy się aby...) tu wymieniamy od razu o co prosimy, podmiot zaś tej modlitwy wypowiadamy jednym tylko słowem, jak np. w wezwaniach drugiej części Litanii do Wszystkich Swiętych.

c) forma niepełna druga (módlmy się za...) gdzie wymieniamy tylko tych, za których się modlimy. Przykłady tej formy znajdujemy w niektórych litaniach błagalnych tak na Wschodzie jak i na Zachodzie.

12. Największe znaczenie ma ta część modlitwy wspólnej, w której wierni wyrażają swój udział. Aby udział ten był na prawdę pełny i żywy, najlepiej jest by wierni odpowiadali na każde wezwanie do modlitwy.

Cztery są tego sposoby:

a) krótka odpowiedź, zawsze ta sama, na każde wezwanie. Ta forma uczestnictwa jest łatwiejsza i przyjęta w tradycji pod nazwą litanii,

b) krótka chwila ciszy po wezwaniu do modlitwy, podczas której wszyscy modlą się w milczeniu; ten udział skupiony był stosowany przez kościół rzymski przy modlitwach w Liturgii Wielkiego Piątku. Nie daje on może wrażenia czynnego udziału, może jednak prowadzić do pełnego rozmodlenia,

c) wspólne odmawianie wezwań litanijnych; ponieważ jednak może to łatwo znużyć jest wskazanym, by zmieniać treść tych wezwań: wierni zaś powinni koniecznie mieć w ręku teksty tych modłóws

d) można też łączyć sposób drugi z pierwszym, to znaczy: po wezwaniu litanijnym następuje chwila ciszy, po czym na znak dany przez diakona wierni wszyscy razem głośno odpowiadają na wezwanie litanijne. Ten sposób odmawiania wspólnych modlitw można zachować np. przy większych uroczystościach.

Jasne jest jednak, że pierwszy sposób jest najodpowiedniejszy, chociaż pozostawia się w tym względzie całkowitą wolność.

13. Czynny udział wiernych jest najistotniejszą cechą owej wspólnej modlitwy i Soborowa Konstytucja o Liturgii świętej domaga się go otwarcie. To też byłoby całkowicie nie na miejscu, gdyby we mszach, 
w których wierni biorą udział na wezwanie litanijne odpowiadała tylko asysta lub Schola cantorum.

14. Na zakończenie wspólnej modlitwy wiernych celebrans a nie kto inny (por. Instr. nr 56) odmawia końcową orację.

\section{§ III. JAK NALEZY STOSOWAĆ W PRAKTYCE WSPÓLNĄ MODLITWE WIERN YCH}

15. Wspólna modlitwa wiernych ma prawdziwie wyrażać modlitwę Kościoła. Kościół zaś jest powszechny, lecz i mocno osadzony w czasie i przestrzeni. A zatem należy sobie życzyć, by zachowana była swoboda w układzie inwokacji oraz ich dostosowaniu do potrzeb rozmaitych krajów i ludzi.

16. Oracja końcowa jak i odpowiedzi wiernych moga być bardziej ujednolicone w poszczególnych krajach czy też obszarach językowych, natomiast może być pozostawiona większa swoboda w doborze intencji oraz sposobie uczestnictwa wiernych. Jednakże, należy zawsze zachować istotne cechy tej wspólnej modlitwy, o których była mowa wyżej.

17. Komisja do wprowadzenia w życie Soborowej Konstytucji o Liturgii świętej przedkłada zasady i normy według których należy ułożyć wspólne modlitwy wiernych w obrządku rzymskim.

18. Episkopaty poszczególnych krajów a jeżeli sprawa tego wymaga to i miejscowi Ordynariusze mają zatwierdzić tekst tych modlitw (por. Instr. nr 56) oraz dostarczyć rektorom kościołów obszerny zbiór intencji modlitewnych.

19. Rektorom kościołów wypada pozostawić swobodę:

a) dowolnego wyboru intencji spośród schematów i formuł zaaprobowanych,

b) dołączenia paru innych intencji prze siebie ułożonych pod warunkiem jeđnak zachowania ogólnego schematu obejmującego cztery rodzaje intencji według tego co powiedziano w $\mathrm{nr} 9$. Poza tym nie wolno mu improwizować w czasie nabożeństwa, tylko musi on posługiwać się tekstem uprzednio przez siebie napisanym.

20. Nie trzeba by wspólna modlitwa wiernych trwała zbyt długo, aby nie była uciążliwą dla wiernych. Dlatego też, odnośna władza może w danym wypadku określić ilość intencji, której nie należy przekraczać. Jednakże i wtedy ta liczba może być przekroczona, jeżeli szczególne okoliczności ku temu skłaniają, np. z okazji pielgrzymki lub przy jakimś wyjątkowym obchodzie.

\section{ROZDZIAE II}

\section{WZORY SCHEMATOW PRZY UKLADANIU WSPÓLNEJ MODLITWY WIERNYCH}

Nie wymaga się bynajmniej wiernego przekładu na różne języki podanych tu wzorów; wypada raczej by je dostosować do mentalności i ducha języka poszczególnych krajów.

Także i termin „modlitwa wspólna” czy też „,modlitwa wiernych” może być oddany innymi słowami, jak np. „modlitwa błagalna”, „modlitwa powszechna", lub według dawnego polskiego zwyczaju ,Wypominki" itp. Zwroty „wspólna modlitwa” oraz „modlitwa wiernych” są zachowane w dokumentach oficjalnych, jako zdawna przyjęte i mające ściśle okre- 
ślone znaczenie. Niemniej ich dosłowny przekład nie zawsze będzie odpowiedni, ponieważ Msza święta jako taka jest też „wspólną modlitwą" a Ojcze nasz jest w najpełniejszym znaczeniu „modlitwą wiernych”.

Wzory tu podane nie wykluczają innych sposobów układania tychże modlitwa zwłaszcza w tych krajach, w których ich zwyczaj już istnieje. (Np. w niektórych okolicach układa się prośby na wzór drugiej części Litanii do Wszystkich Swiętych).

\section{PIERWSZY SCHEMAT}

\section{(ogólny)}

A) (Wezwanie do modlitwy, por. wyżej nr 7).

Bracia najmilsi, módlmy się całym sercem do Boga Ojca Wszechmogącego, który chce, by wszyscy ludzie byli zbawieni i dostąpili poznania prawdy.

B) (1-sza seria intencji) (por. wyżej n. 9. B.).

Módlmy się za święty Kościół Boży: aby Pan raczył go strzec i zachować.

(wierni por. wyżej n. 12 a).

Spraw to Boże Wszechmogący. (Można wedle uznania, używać podanego tu wezwania, czy też innego spośród niżej przytoczonych, czy też, jeszcze jakiegoś innego, byleby tylko były one dostosowane za. zarówno do podanych intencji jak i do wezwania celebrującego kapłana. Np. jeżeli mówimy: „Módlmy się do Boga, Ojca Wszechmogącego..." nie należy odpowiadać „Chryste, zmiłuj się".

Można także użyć innego sposobu uczestniczenia wiernych, jeżeli wydaje się on bardziej wskazany. Przykłady podane są wyżej n. 12 b, c, d.).

C) (2-ga seria intencji por. wyżej n. 9. C.).

Módlmy się za wśzystkie narody świata: ażeby Pan raczył zachować pokój pomiędży nimi.

- Spraw to, Boże Wszechmocny.

D) (3-cia seria intencji por. wyżej n. 9. D).

Módlmy się za wszystkich znajdujących się w ucisku: ażeby Bóg wesprzeć ich raczył.

- Spraw to, Boże Wszechmocny.

E) (4-ta seria intencji por. wyżej n. 9. E).

Módlmy się i za nas tu zebranych i za naszą społeczność: ażeby Pan jako ofiarę godną siebie przyjąć nas raczył.

- Spraw to, Boże Wszechmocny.

F) (Modlitwa końcowa odmawiana przez Celebransa por. wyżej n. 14). (bez „módlmy się”) Wszechmocny wieczny Boże, Ty zbawiasz wszystkich i nie chcesz by ktokolwiek zginął, prosimy, wysłuchaj błagań Twego ludu i spraw, by Opatrzność Twoja ustrzegła świat od wszelkiego złego i by Kościół twój cieszył się dobrem pokoju. Przez Chrystusa Pana naszego.

(wierni odpowiadają): Amen.

\section{DRUGI SCHEMAT}

\section{(ogólny)}

A) Rozpoczynamy teraz, bracia, wspólną modlitwę. Pamiętajmy abyśmy nie modlili się wyłącznie za siebie $i \mathrm{w}$ swoich tylko intencjach, ale razem, wspólnie, módlmy się do Pana naszego wszyscy za wszystkich. 
B) Za cały lud chrześcijański - o obfitość Bożej dobroci błagajmy:

- Chryste, wysłuchaj nas

2. Za tych, którzy jeszcze nie uwierzyli o dary duchowne prosimy:

- Chryste, wysłuchaj nas.

C) 1. Za rządzących państwami — pomoc Bożą wypraszajmy:

- Chryste, wysłuchaj nas.

2. O pogodę i urodzaje - Tego, który wszystkim rządzi błagajmy: - Chryste, wysłuchaj nas.

D) 1. Za braci naszych nieobecnych, Tego, który wszystkiego dogląda prosimy:

- Chryste, wysłuchaj nas.

2. Wieczny odpoczynek dla zmarłych u Chrystusa sędziego wypraszajmy:

- Chryste, wysłuchaj nas.

E) 1. O dobre wyniki misji (rekolekcji) dla naszej parafii, łaskawego Zbawiciela prośmy:

- Chryste, wysłuchaj nas.

2. Za N., który w przyszłą sobotę ma otrzymać święcenia - Wiekuistego Kapłana prośmy:

- Chryste, wysłuchaj nas.

F) Nastaw uszy łaskawości Twej, Panie, na prośby nasze, i błagania proszących Cię życzliwie wysłuchaj: Przez Chrystusa Pana naszego. Amen.

\section{TRZECI SCHEMAT}

(na czas adwentu)

A) Modlitwami uprzedzając przyjście Pana naszego Jezusa Chrystusa, bracia najmilsi, Jego miłosierdzie usilnie błagajmy, aby On, który dla ewangelizowania ubogich i leczenia skruszonych serc przyszedł na ten świat, także w obecnym czasie, wszystkim potrzebującym dał zbawienie.

B) 1. Ażeby Kościół swój święty nawiedził i zawsze nim rządził, prośmy Pana:

- Kyrie eleison.

2. Ażeby Ojca świętego, biskupa naszego i cały episkopat napełnił darami, duchowymi łaskami, prośmy Pana:

- Kyrie eleison.

C) 1. Ażeby za Jego łaską czasy nasze były spokojne, prośmy Pana: - Kyrie eleison.

2. Ażeby myśli tych, którzy nami rządzą kierował według swej woli dla pozyskania dóbr wszelakich, prośmy Pana:

- Kyrie eleison.

D) 1. Ażeby choroby i głód oddalił, i wszelkie niepokoje odwrócił -prośmy Pana:

- Kyrie eleison.

2. Ażeby wszystkich prześladowanych litościwie uwolnił - Prośmy Pana:

- Kyrie eleison.

E) 1. Abyśmy w całej prawdzie byli wobec ludzi świadkami dobroci Bożej - Prośmy Pana:

- Kyrie eleison.

2. Aby nas w godzinie przyjścia swego jako sługi, czuwających i gotowych napotkał - prośmy Pana:

- Kyrie eleison. 
. F) Panie, ucieczko nasza i mocy, usłysz pobożne modlitwy Kościoia, które są przecież Twoim dziełem, i spraw, abyśmy to wszystko, o co prosimy, rzeczywiściẹ zyskali. Przez Chrystusa Pana naszego.

\section{CZWARTY SCHEMAT}

(podczas pogrzebu i mszy żałobnej)

A) Boga Ojca wszechmogącego, który Syna swego wskrzesił z martwych, prosić będziemy o zbawienie dla żywych i umarłych.

B) Ażeby lud swój chrześcijański, w̉ jedności wiary ustalił - Błagajmy Pana:

- Ciebie błagamy, wszechmogący Boże.

C) Ażeby świat cały uwolnił od nieszczęść wojny - błagajmy Pana:

- Ciebie błagamy, wszechmogący Boże.

D) Ażeby się okazał Ojcem, zwłaszcza dla bezrobotnych, głodnych i bezdomnych - błagajmy Pana:

- Ciebie błagamy, wszechmogący Boże.

E) (por. wyżej n. 9)

E) 1. Za tego zmarłego N., który przez chrzest otrzymał zaród życia wiecznego - ażeby też na zawsze otrzymał towarzystwo świętych w niebie - błagajmy Pana:

- Ciebie błagamy, wszechmogący Boże.

2. Za niego, który pożywał Ciało Chrystusa, chleb żywota wiecznego, ażeby go wskrzesił w dniu ostatecznym - błagajmy Pana:

- Ciebie błagamy, wszechmogący Boże.

(albo, jeśli zmarły był kapłanem: za niego, który w Kościele spełniał urząd kapłański, ażeby mu dał udział w liturgii niebieskiej, błagajmy Pana:

- Ciebie błagamy, wszechmogący Boże.

3. Za dusze braci, krewnych dobrodziejów naszych, aby otrzymali nagrodę za swe trudy — błagajmy Pana:

- Ciebie błagamy, wszechmogący Boże.

4. Za wszystkich, którzy pomarli w nadziei zmartwychwstania, aby ich przyjął w jasności oblicza swego, błagajmy Pana:

- Ciebie błagamy, wszechmogący Boże.

5. Za braci naszych, którzy obecnie cierpią, aby ich wspomógł i pocieszył - błagajmy Pana:

- Ciebie błagamy, wszechmogący Boże.

6. Za nas wszystkich, którzyśmy tu przybyli z wiarą i pobożnością, aby nas zjednoczył w chwalebnym królestwie swoim — błagajmy Pana:

- Ciebie błagamy, wszechmogący Boże.

F) Prosimy Cię, Panie, niech pokorna modlitwa nasza pomocną będzie duszom sług i służebnic twoich; racz je oczyścić od wszystkich grzechów i dopuścić do udziału w owocach Twojego odkupienia. Przez Chrystusa...

\section{PIĄTY SCHEMAT}

(równiė̇ na czas pogrzebu czy mszy żałobnej)

A) Obecnie, bracia, klęknijmy do modlitwy, w której prosić będziemy już nie tylko w intencji naszego zmarłego, ale też za Kościół, o pokój dla całego świata i o zbawienie dla nas wszystkich. Pana Boga naszego błagajmy. 
B) Zạ wszystkich pasterzy Kościoła; aby to co głoszą słowem, wykonali uczynkiem:

- Wysłuchaj, Panie, i spraw to litościwie.

C) Za wszystkich zwierzchników Ojczyzny, aby służyli pokojowi i sprawiedliwości:

- Wysłuchaj, Panie, i spraw to litościwie.

D) Za wszystkich, którzy boleści doznają na duszy czy na ciele, aby nigdy nie myśleli, że ich Bóg opuścił:

- Wysłuchaj, Panie, i spraw to litościwie.

E) (por. wyżej nr. 10):

1. Aby Bóg duszę sługi swego zmarłego N. spod panowania ciemności i od kary uwolnić raczył:

- Wysłuchaj, Panie i spraw to litościwie.

2. Aby wszystkie jego grzechy puścił w niepamięć wiekuistą:

- Wysłuchaj, Panie i spraw to litościwie.

3. 'Aby go Bóg przy sobie $\mathrm{w}$ spokoju i światłości umieścić raczył: - Wysłuchaj, Panie i spraw to litościwie.

4. Aby mu szczęśliwości i towarzystwa świętych i wybranych udzielié raczył:

- Wysłuçhaj, Panie i spraw to litościwie.

5. Za wszystkich zmarłych bliźnich i dobrodziejów... Aby ich do swej światłości wiekuistej przyjąć raczył:

- Wysłuchaj, Panie i spraw to litościwie.

6. Za wszystkich wiernych zmarłych.

Aby ich w królestwie niebieskim umieścić raczył:

- Wysłuchaj, Panie i spraw to litościwie.

F) Boże, Stwórco i Odkupicielu wszystkich wiernych, udziel duszom zmarłych sług i służebnic twoich odpuszczenia wszystkich grzechów: niech przez pobożne modły nasze dostąpią miłosierdzia, którego zawsze pragnęly. Przez Chrystusa Pana naszego.

\section{SZÓSTY SCHEMAT \\ (w czasie obrzędów ślubnych)}

A) Ukochani bracia, módlmy się wspólnie o pokój dla całego świata, o szczęśliwe warunki pracy dla Kościoła, o jedność (i zgodę) dla wszystkich ludzi - a zwłaszcza prosić będziemy Chrystusa Pana w intencji tych, którzy się w stadło małżeńskie łączą.

B) $\mathrm{Za}$ cały lud chrześcijański: aby $\mathrm{z}$ dnia na dzień wzrastał $\mathrm{w}$ mocy, Chrystusa Pana błagajmy:

- Ciebie prosimy, wysłuchaj nas, Panie.

D) Za tych, których nękają przeciwności i. krzywdy, albo jakiekolwiek nieszczęścia, aby ich wspomógł i wyzwolił - Chrystusa Pana błagajmy:

- Ciebie prosimy, wysłuchaj nas, Panie.

(tu przedstawia się intencja. C i D, aby uniknąć niekorzystnego zestawienia małżeństwa i nieszczęść).

C) O pokój dla całegơ świata, ażeby każdy według swych możliwości nad zachowaniem pokoju pracował - Pana błagajmy:

- Ciebie prosimy, wysłuchaj nas, Panie.

E) por. wyżej $\mathrm{nr} 10$

1. Za tych wiernych chrześcijan N. i N. obecnie małżeństwem połączonych, o zbawienne pomoce dla nich Pana błagajmy:

- Ciebie prosimy, wysłuchaj nas, Panie. 
2. Aby błogosławił temu związkowi, tak jak ongiś uświęcił gody w Kanie Galilejskiej, Pana błagajmy:

- Ciebie prosimy, wysłuchaj nas, Panie.

3. Aby dał im dzieci, dla utrzymania gatunku, Pana błagajmy: - Ciebie prosimy, wysłuchaj nas, Panie.

4. Aby dał im miłość doskonałą, pokój i pomoc, Pana błagajmy: - Ciebie prosimy, wysłuchaj nas, Panie.

5. Aby ich zachował w zgodzie i wierności, aby dawali dobre świadectwo imieniowi chrześcijańskiemu, Pana błagajmy:

- Ciebie prosimy, wysłuchaj nas, Panie.

6. Aby przez Ducha świętego odnowił łaski Sakramentu Małżeństwa wszystkim obecnym tu małżonkom. Pana błagajmy.

- Ciebie prosimy, wysłuchaj nas, Panie.

7. Aby wszystkich bliźnich naszych, którzy już z tego świata zeszli, do niebieskiej szczęśliwości przyjąć raczył. Pana błagajmy:

- Ciebie prosimy, wysłuchaj nas, Panie.

F) Wszechmocny, wieczny Boże, spójrz łaskawie na te sługi Twoje i daj im w Tobie tylko ufającym dary laski Twojej. Niech zachowają miłość w jeđności. Niech w tym życiu zasłużą sobie wraz z potomstwem swoim na radości wiekuistego szczęścia. Przez Chrystusa, Pana naszego.

\section{INNE MODLITWY KOÑCOWE}

1. Wysłuchaj, Panie, próśb ludu Twego i niech Twa uprzedzająca łaska udziela nam czegokolwiek brakuje zasługom tych, którzy Cię proszą. Przez Chrystusa...

\section{(Sakramentarz z Verony)}

2. Niech się raduje, prosimy Cię, Panie, lud Twój wyproszonymi dobrodziejstwami. Daruj im litościwie to, o co, Tobie zawierzywszy, modlą się z ufnością. Przez Chrystusa...

(Sakramentarz z Vicenzy)

3. Wejrzyj, Panie, na lud kornie proszący, i towarzysz mu laskawie, gdy pokłada ufność w Twoim miłosierdziu. On bez Ciebie nawet istnieć nie może, kieruj więc nim tak przez doczesne dobrodziejstwa, aby wiekuiste radości pozyskał. Przez Chrystusa...

(Sakramentarz z Verony)

4. Podaj prawicę, prosimy Cię, Panie, ludowi Twemu, błagającemu o miłosierdzie, przez które niech uniknie tego, czego się człowiek lęka, pomoce w życiu doczesnym pozyska i wiekuiste radości osiągnie. Przez Chrystusa...

(tamże)

5. Wejrzyj, Panie, na prośby rodziny twojej i wspomóż ją, nasyć i umocnij, gdy całym sercem poddaje się Tobie, aby zawierzając Twej Opatrzności, żadnego zła nie zaznała, a przeciwnie napełniła się dobrem. Przez Chrystusa.

\section{(tamże)}

6. Wysłuchaj, Panie, próśb naszych, i uczyń, abyśmy poddani zawsze majestatowi Twemu, tym łatwiej jednali sobie dary łaski Twojej.

(tamże)

7. Panie, daj się przebłagać naszymi modłami, aby zaś niczyje pragnienie nie, było bezskuteczne, niczyja prośba daremna, spraw, abyśmy otrzymali to, o co z wiarą prosimy. Przez Chrystusa.

(Mszał rzymski) 
8. Wszechmogący, wieczny Boże, który rządzisz niebem i ziemią, wysłuchaj łaskawie próśb ludu Twojego i racz obdarzyć nasze czasy Twoim pokojem. Przez Chrystusa.

\section{(Mszał rzymski)}

- 9. Panie, niech uszy miłosierdzia Twego otworzą się na modlitwy tych, którzy Cię błagamy i abyś mógł spełnić ich pragnienia, daj im prosić o to, co'się Tobie podoba. Przez Chrystusa.

(Mszał rzymski)

10. Wszechmogący wieczny Boże, w nadmiarze swojej dobroci przewyższasz zasługi i. pragnienia błagających Cię; zlej na nas miłosierdzie swoje i odpuść to, co niepokoi sumienia, a użycz tego, co nie ośmielamy się modlić. Przez Chrystusa.

\section{(Mszał rzymski)}

11. Boże, który wiesz, że życie ludzi tu obecnych podlega przeróżnym potrzebom, wysłuchaj pragnienia tych, którzy Cię błagają i przyjmij intencje Twoich wiernych, Przez Chrystusa.

(Mszał rzymski)

12. Prosimy Cię, Panie, niechże łaskawość Twoja towarzyszy błaganiom ludu, aby to o co prosi pod Twoim natchnieniem, z hojności Twojej otrzymał. Przez Chrystusa.

\section{(Sakramentarz z Verony)}

13. Panie Boże, królu nieba i ziemi, Ty wszystkoś stworzył i wszystkim rządzisz - wysłuchaj prośby nasze i daj wszystkim Twoim wiernym wytrwać w prawdziwej wierze i w dobrych uczynkach; daj niewiernym zbawienne nawrócenie do Ciebie, daj abyśmy tak jak i oni, służyli Ci zawsze w gronie wybranych, Przez Chrystusa.

\section{(Mszał Leofryka z Exeter)}

14. Niechże modlitwa nasza wstąpi aż do tronu świętości Twojej i niech nie pozostanie daremną nasza prośba. Przez Chrystusa.

(Mszał Stowe)

15. Prosimy Cię, Panie, przyjmij łaskawie modlitwy Swojego Kościoła, aby pokonawszy wszelkie przeciwności i błędy, służył Ci w bezpiecznej wolności. Przez Chrystusa.

\section{(Mszał rzymski)}

16. Boże, Ty jeden znasz liczbę wybranych, którzy się mają znaleść w niebieskiej szczęśliwości; daj, prosimy, aby za przyczyną wszystkich świętych Twoich, imiona tych, których polecono naszym modlitwom oraz wszystkich wiernych zachowała spisana księga wybranych do szczęśliwości. Przez Chrystusa.

(Mszał rzymski)

\section{DODATEK}

\section{HISTORIA WYPOMINKÓW CZYLI WSPÓLNEJ MODLITWY WIERNYCH}

1. Modlitwę wiernych znajdujemy dzisiaj we wszystkich prawie obrządkach, wydaje się nawet, że dawniej posiadały ją wszystkie obrządki. Jej początki odnosi się do czasów apostolskich albo i synagogalnych nawet, jeśli urywek 1 Listu do Tymoteusza 2, 1-4, przytoczony przez Konstytucję o Liturgii świętej, nie ma na myśli tej właśnie modlitwy liturgicznej, a jedynie chrześcijański obowiązek modlitwy w ogóle. 
2. Natomiast oczywisty związek $z$ wypominkami odnajdujemy w zakończeniu listu św. Klemensa do Koryntian. Następca Piotra przy końcu swej egzorty wzywa Koryntian, aby „modlono się do Stwórcy wszechrzeczy, usilnie prosząc Go i błagając, żeby na całej ziemi strzegł i zachował wszystkich bez wyjątku swoich wybranych, przez sługę swego Jezusa Chrystusa".

Następnie i bezpośrednio po tym, Klemens zwraca się do Boga prosząc Go w uroczystej modlitwie za cały lud Boży, za wszystkich, którzy znajdują się w ucisku, za odpuszczenie grzechów, o pokój i za władców i kończy wspaniałą doksologią.

3. Pierwszą jasną wzmiankę o wypominkach jako części składowej liturgii, po homilii czy też udzielonym chrzcie a przed pocałunkiem pokoju i Liturgią eucharystyczną, znajdujemy u św. Justyna Apologety (I Apol., rok 150). pisze on tak:

„(w niedziele, po odczytaniu Pisma i homilii przewodniczącego) stoimy wszyscy razem i modlimy się (67); w odniesieniu zaś do chrztu: ,wprowadzamy nowoochrzczonego w społeczność braci, modlimy się też wspólnie za nas samych, za tego, który przyjął chrzest, za wszystkich też innych gdziekolwiek się znajdują, abyśmy stali się godnymi prawdy, którą poznajemy, abyśmy uczciwie postępowali i zachowywali przykazania tak, aby dostąpić wiecznego zbawienia".

Justyn wyraźnie odróżnia owe wypominki od ofiary eucharystycznej i modlitwy, którą przewodniczący zebraniu wypowiada nad przyniesionym chlebem i winem, a na końcu której zebrani odpowiadają: Amen.

4. Na początku III w. św. Hipolit w dziele Traditio apostolica przepisuje podobnie, aby zaraz po przyjęciu chrztu nowoochrzczony „wraz ze wszystkimi wiernymi modlili się wspólnie i nie czynili tego zanim obrzęd chrzcielny nie będzie ukończony". Następuje pocałunek pokoju a potem ofiarowanie chleba i wina (Ed. Botte, Münster, 1963, 54, Paryż 1946, 53).

5. Wielu Ojców Kościoła wspomina często ową wspólną modlitwę wiernych (np. na Zachodzie: Cyprian, Tertulian, Ambroży, Arnobiusz, Augustyn, Syryciusz; na Wschodzie: Klemens, Dionizy Aleksandryjski, Orygenes, Atanazy, Jan Złotousty i inni). Co prawda z niektórych tekstów nie wynika jasno czy chodzi o wspólną modlitwę podczas akcji liturgicznej, niemniej jednak w większości wypadków owe wzmianki do niej się odnoszą.

Wyżej przytoczone świadectwa Ojców Kościoła II i IV w., nie podaja jednak szczegółów odnośnie do struktury tejże modlitwy oraz intencji w niej wymienionych. Tertulian (Apologeticus 39, 2) wspomina mimochodem, że ,chrześcijanie modlą się także i za cesarzy, za wszystkich, którzy w ich imieniu sprawują władzę, za sprawy doczesne, za pokój i ażeby dzień ostateczny nie przyszedł niespodziewanie”. Ambroży zaś: „należy w modlitwie pamiętać o wiernych, o władcach i o wszystkich innych". (De sacramentis, 4, 14).

6. Uroczyste modlitwy liturgii Wielkiego Piątku są najdawniejszym świadectwem wspólnej modlitwy wiernych w obrządku łacińskim; Baumstark i Jungmann odnoszą ten tekst do III wieku; przytacza go w wieku V Prosper z Aquitanii; w następstwie spotykamy go tylko w Wielki Piątek, lecz Ordo romanus $10 \mathrm{z}$ początku VIII w. świadczy, że posługiwano się tym tekstem nie tylko w W. Piątek ale i w Wielką Srodę.

Jak wiadomo owe modlitwy wyliczają dziewięć intencji: za Kościół, za Ojca świętego, za Duchowieństwo i wiernych, za imperatora rzymskiego, za katechumenów, za wszystkich potrzebujących pomocy, za heretyków i schizmatyków, za żydów i za pogan.

Struktura tej modlitwy jest następująca: 
a) za każdym razem celebrans wzywa wiernych do modlitwy podając im intencję: módlmy się... za... ażeby...

b) po każdym wezwaniu do modlitwy wierni klękają na znak dany przez diakona i modlą się $\mathrm{w}$ milczeniu,

c) nastẹpnie, również na znak dany przez diakona, powstają a celebrans głośno odmawia modlitwę w intencji uprzednio podanej,

d) wierni zaś lączą się czynnie z tą modlitwą odpowiadając na nią: Amen.

7. Na Wschodzie istniała inna forma owej wspólnej modlitwy, mianowicie litania. Liturgia rzymska przyswoiła ją sobie pod koniec V wieku.

Wygląda ona następująco:

a) Diakon zapowiada intencję w której należy się modlić. Czyni to albo w formie pełnej, tak jak w obrządku rzymskim (módlmy się... za... ażeby...) albo w formie skróconej: módlmy się aby... lub też: módlmy się za... W tej ostatniej formie nie podaje się treści intencji lecz za kogo należy się modlić. Wraz ze skróconą formą intencji wzrasta też ich liczioa i pojawiają się nowe: o zbiory, za dobroczyńców, za zmarłych itd., wylicza się też intencje dotyczące zebranych na nabożeństwie: odpuszczenie grzechów, anioł stróż, życie chrześcijańskie, dobra śmierć itd.

b) $\mathrm{Na}$ każde wezwanie diakona wierni odpowiadają krótką modlitwą błagalną; w miarę jak wzrasta liczba intencji owe odpowiedzi wiernych powtarzają się parokrotnie za każdym razem aż do 5, 10 czy 20 razy (Testamentum Domini, tekst synajski. V wiek). Albo też po 5 i 3 razy (Testamentum Domini, tekst liturgii etiopskiej).

c) Kapłan w tych intencjach za każdym razem modli się głośno czy to po paru intencjach naraz czy też raz tylko na końcu.

(Por. Roghetti, Storia liturgica, 3, Milano 1949, 244).

Pierwsze ustawodawstwo $w$ tej sprawie na Wschodzie znajdujemy w kan. 19 Soboru w Laodycei w połowie IV w. - przed rokiem 381 -: ,należy najpierw" odmawiać osobno modlitwy za katechumenów, po przemówieniach episkopów, a po wyjściu katechumenów, za pokutników. Po wyjściu tychże... następują trzy modlitwy wiernych w ten sposób, że pierwsza odbywa się 'w milczeniu, na drugą zaś i trzecią wierni odpowiadają jak zazwyczaj; po czym daje się pocałunek pokoju... na koniec składa się dary ofiarne".

(H efele-Leclercq, Histoire des Conciles, 1, 1010).

8. Trudno jest orzec ezy jest to pierwotna forma wspólnej modlitwy w liturgiach wschodnich, zwłaszcza jeżeli chodzi o Syrię. Wydaje się bowiem, że niektóre teksty pochodzą dopiero z III w. Lecz jakiekolwiek byłyby początki wszędzie pod koniec IV w. spotykamy na Wschodzie tę formę już w pełni ustaloną.

W następnych wiekach zwyczaj ten przyjął się szybko i na Zachodzie często wypierając lokalną formę wypominków. W ten sposób pojawiają sie: litania celtycko-germańska tzw. Deprecatio Sancti Martini, litania ambrozjańska Divinae pacis używana dotąd w Mediolanie w okresie Wielkiego Postu (obie są zresztą dosłownym tłumaczeniem tekstu greckiego ${ }^{1}$ ) oraz w Rzymie Deprecatio Gelasii Papae, dosyć przeciętna jeżeli chodzi o tekst.

1) Zdaje się, że stąd wywodzi się ostatnia część litanii do Wszystkich Swiętych - por. B is h o p, Liturgica historica, 142 - powstanie tych litanii nie jest jasme, wiemy jednak, że za czasów Karola Wielkiego posługiwano się nimi przy wypominkach, ale nie we mszy św., lecz w procesjach.

1 Pomija się dodatek $\mathrm{z}$ wzorami melodii. 
Owa deprecatio została wprowadzona przy końcu $\mathrm{V}$ wieku i połączona od samego początku lub wkrótce potem $z$ pieśnią na wejście mszy św. papieskiej. Wyparła też ona, z wyjątkiem Wielkiego Tygodnia starożytną formę rzymską wypominków dopóki z kolei nie zastąpiono jej przy końcu VII wieku prostą aklamacją: Kyrie eleison.

9. Wspólna modlitwa wiernych odbywała się nie tylko podczas mszy św., ale też — jak z powyższych uwag wynika - i na zakończenie innych jeszcze uroczystych nabożeństw.

Najdawniejsza forma rzymska tej oracji dochowała się przy końcu Liturgii Słowa w Wielki Piątek; litanię zaś znajdujemy w obrządkach bizantyńskim, ormiańskim i innych przy końcu jutrzni i nieszporów; miał ją dawniej i obrządek rzymski, o czym świadczą preces feriales et dominicales zamieszczone w brewiarzu.

10. Na Wschodzie w IV wieku, potem także i w Rzymie wprowadzono modlitwę wstawienniczą kapłana (intercessio sacerdotalis) przy końcu anafory lub w kanonie mszy św.; podejmuje ona owe intencje a często té̇ powtarza dosłownie starodawne wspólne modlitwy, jak o tym mówią liczne świadectwa a także $i$ wszystkie obrządki $z$ wyjątkiem mozarabskiego. (Obrządek mozarabski ma komemorację składających dary w czasię, gdy przynoszone są one do ołtarza tzn. w czasie ,ofertorium”).

11. W liturgii wizygockiej w Hiszpanii (a także w liturgiach galikańskich) istniał, jak się zdaje, miejscowy zwyczaj wspólnej modlitwy: obejmowała ona wezwanie do modlitwy, wypowiedziane przez kapłana, i skierowane do wiernych (w Galii zwano ją prefacją mszalną), następnie intencje, o które miano się modlić.

12. Tam, gdzie obrządek rzymski wyparł obrządki gallikańskie zachowano zawsze $w$ niedziele jakieś wspólne modlitwy $i$ to zazwyczaj pod koniec Liturgii Słowa; przed rozpoczęciem Liturgii Ofiary. Dowody istniejącej w Galii wspólnej modlitwy wiernych przytacza Synod Lyoński w 517, który wspomina „modlitwę wiernych odmawianą po Ewangelii" oraz Expositio Missae przypisywane Germanowi z Paryża (w. VII), gdzie jest mowa o litanii diakona w łączności z modlitwą kapłana.

Owe zwyczaje gallikańskie przeszły prawdopodobnie do mszału rzymskiego w formie wspólnych modlitw, które znajdujemy w niektórych dokumentach germańskich i lotaryńskich (tak np. w Missale Leofrici Exoniensis), celtyckich i anglosaskich (Missale Drummodiense, Evangelium Eboracense) w IX, X i XI wieku.

13. W germańskich i gallikańskich zbiorach prawa kanonicznego z początku X w., umieszczany jest kanon wzięty, jak mówią źródła, z Synodu w Orleanie. Oto jego tekst: „Oportet ut in diebus dominicis vel festis post sermonem intra Missarum solemnia habitum ad plebem, sacerdos admoneat, ut iuxta apostolicam institutionem, orationem omnes in communi pro diversis necessitatibus fundant ad Dominum: pro rege et episcopo eorum, et rectoribus ecclesiarum, pro pace, pro peste, pro infirmis, qui in ipsa parochia lecto decumbunt, pro nuper defunctis; in quibus singillatim precibus plebs orationem dominicam sub silentio dicat; sacerdos vero orationes ad hoc pertinentes per singulas admonitiones solemniter expleat. Post haec sacra celebretur oblatio" (Mansi, VII, 361; PL. 132, 224; 140, 658; 161, 193).

14. Z XII wieku posiadamy różne wzory wspólnej modlitwy po homilii $\dot{w}$ Niemczech i Czechach; pomiędzy tymi świadectwami pierwsze miejsce należy się tekstowi znajdującemu się w homiliarzu zatytułowanym „Speculum Ecclesiae” Honoriusza z Autun. Modlitwa zaczyna się od ekshortacji: „Fratres... non debetis hic otiosi stare, sed pro vobismetipsis et pro tota Ecclesia sancta Dei orare, ut Deus... dignetur eam pacificare, 
- etc. „Następuje 14 długich inwokacji litanijnych dotyczących: Kościoła i duchowieństwa (4), króla i przełożonych (2), tych, którzy znajdują się w przeciwnościach (5), całego ludu chrześcijańskiego (1), celebransa (1), zebranych w kościele (1). Modlitwa kończy się słowami: „Eia, nunc preces vestras alta voce ferte ad coelum, et cantate in laudem Dei: „Kyrie eleison".

15. Powyższy tekst stał się prawdopodobnie modelem według którego układano $\mathrm{w}$ następstwie $\mathrm{w}$ średniowieczu wezwania litanijne (zwane w Galii „Formules du Prône” albo „Prières du Prône”). O tych wypominkach mamy świadectwa lub teksty na przestrzeni od XIII do XVI W., ze wszystkich prawie krajów, które przyjęły obrządek rzymski: a więc Hiszpania, Galia, Anglia, Niemcy, Irlandia, Polska, Czechy a takze i z miasta Sieny w Italii. Ten tekst jest następujący: „Omni die dominico... septimanarius... orat populum ut oret pro pace, et pro his, qui vadunt stant ad servitium Dei, ut eis Deus... et nobis sic concedat vivere in hoc saeculo, quod cum ipsis in regno coelorum partem possimus habere. Item pro infirmis in animo vel corpore, ut... Postea moneat ut oret populus pro animabus defunctorum... Et dicat ut cantent Pater noster, et clerus dicat psalmum..."

W późnym średniowieczu kapłan podawał około dwanaście lub piętnaście intencji: „Módlcie się (lub: Módlmy się) za... aby...", następnie duchowieństwo odmawiało często jeden lub dwa psalmy i wezwania modlitewne, a wierni mówili po cichu Ojcze nasz.

Dotychczas nie posiadamy żadnych świadectw o tego rodzaju modilitwach w Rzymie.

16. Począwszy od Reformacji (w. XVI) a zwłaszcza po Soborze Trydenckim ta średniowieczna forma wspólnej modlitwy wiernych uległa wielkim zmianom w większości krajów.

W Italii, Hiszpanii oraz w Polsce pod wpływem nowych ksiąg liturgicznych rzymskich oraz nabożeństw ludowych owe modlitwy zanikły stopniowo lưb od razu.

W Niemczech zastąpiono je i to aż do naszych czasów, piękną modlitwą ułożoną przez Piotra Kanizjusza w r. 1556; jest to zbiorowa modlitwa wiernych skierowana do Boga. Potem przekształcono ją we formę litanijną, w której wierni biọrą czynny udział, zazwyczaj po wymienieniu przez celebransa lub komentatora intencji modlitw według modelu proponowanego przez Kanizjusza.

W Galii ,preces pronai” (jak je zwano) zostały raptem w XVII w. przeniesione przed kazanie i obciążone różnymi pouczeniami; z biegiem czasu stopniowo zanikały, lecz ich pamiątka przechowała się aż do dzisiaj w szczątkowej formie.

17. Bossuet dơskonale podkreśla znaczenie tej wspólnej modlitwy wiernych w 2-ej części swego Katechizmu diecezjalnego (1687):

- „Dlaczego lepiej jest wysłuchać mszy św. parafialnej niż jakiejkolwiek innej?

- Dlatego, że na tej mszy zbierają się wierni.

- Dlaczego jeszcze?

— Dlatego, że na tej mszy parafialnej jest ,pronaus” (wypominki).

- A cóż to jest pronaus (wypominki)?

- Składa się on z dwóch głównych części.

- Jakie są te części?

- Po pierwsze wspólna modlitwa przez Boga nakazana za Kościół po- 
wszechny, za duchowieństwo, za panujących, za chorych, za uciśntonych, za wszystkie potrzeby ludu Bożego tak ogólnie jak i partykularnie.

- Czy taka modlitwa jest przyjęta przez Boga?

- Bez wątpienia, zwłaszcza gdy jest wspólnie odmawiana przez duszpasterza i wiernych razem zgromadzonych".

(Catéchisme du Diocèse de Meaux, Paris 1687, 2-a p. str. 4-5).

Tyniec

ttumaczyt O. P. SCZANIECKI OSB.

\section{Ks. Jan Kruppik, Poznań}

\section{ROLA LITURGII W KATECHEZIE MLODZIEZOOWEJ}

1. W. u biegły $\mathrm{m}$ pięćdziesięci o leciu młodzieżowe programy nauki religii niedwuznacznie zdradzały swoją zależność od programów wykładu teologii w seminariach duchownych. W seminaryjnych programach zawsze pierwsze miejsce zajmowała dogmatyka i etyka, po nich — dyscypliny biblistyki i historii; liturgia zaś (jako rubrycystyka) wraz z praktyką śpiewu kościelnego znalazla się na szarym końcu jako nauka praktyczna. Programy nauki religii szkół średnich wykazały strukturę identyczną. Na ogół nie przewidywały osobnych lekcji liturgicznych, pozwalały jednak katechecie uzupełnić zasadniczy wykład liturgicznymi informacjami. W tym celu drukowało się tė̇ zwięzłe ,liturgiki” szkolne.

Budzący się silnie po I wojnie światowej ruch liturgiczny zaznaczył niebawem swój wpływ na polu nauki religii: w polskim programie gimnazjalnym znalazła się w klasie IV (odṕowiadającej dzisiejszej VII) całoroczna nauka ,liturgii" (nie 'liturgiki), a jako podręcznik wprowadzono stosownie wydany mszał rzymski. Była to nowośé, która przyjęla się dość łatwo w katechezie polskiej i przetrwała do czasów powojennych.

Za granica przyznano liturgii w nauce religii w szerokim zakresie funkcję dydaktycznej ilustracji tez dogmatyczno-etycznych. W podręcznikach znalazły się w każdym paragrafie dodatki liturgiczne, wyrażające istotę danego problemu w języku liturgii i jej symbolach. Ilustrację plastyczną tworzyły doskonałe reprodukcje dzieł sztuki kościelnej, wprowadzające do dialektyki pożądany element przeżycia uczuciowego.

Trzeba zadać sobie pytanie, czy pow̉yższe próby dydaktyczne z których ì obecnym polskim programie nie pozostał żaden ślad uznać można za najpełniejsze wyczerpanie wszystkich możliwości dydaktyczno-wychowawczych liturgii katolickiej? - Wyjaśnień szukać nam wypadnie $m$. in. w historii Kościoła.

2. W dziejach Kościoła. W pierwotnym Kościele nạka apostolska wiązała się organicznie z praktyką życia nadprzyrodzonego, służąc przygotowaniu duszy w jej zjednoczeniu z Bogiem. Ta praktyka i zasada utrwaliła i pogłębiła się w dziejach Kościoła w tej 